\title{
The Collateral Damage of Sodium Nitrates and Alleviating Properties of Vitamin C on Thyroid Gland of Adult Male Albino Rats: Toxicological, Histological and Ultrastructural study
}

\author{
Zienab A. Gouda', Mahmoud A. Ismail², Eman M. Askar¹, and Zakaria A. El- \\ Zawahry $^{2}$
}

${ }^{1}$ Histology and Cell Biology Department
${ }^{2}$ Department of Forensic Medicine and Clinical Toxicology

Faculty of Medicine, Zagazig University, Zagazig, Egypt.

Corresponding author

Mahmoud A. Ismail, Tel.: 01115119591, E-mail: awadyme@gmail.com

\begin{abstract}
Introduction: In the recent years, a considerable attention has been paid to the problem of nitrates due to their intensive use as agricultural fertilizers which reach to humans and animals by different routes. Purpose: To validate the toxic effects of nitrates in a short-term experiment (60 days) on thyroid gland and the possible ameliorative effect(s) of vitamin $\mathrm{C}$.

Materials and methods: Thirty two adult male albino rats were divided into four groups: group I (control) received distilled water, group II received 500mgkg vitamin C, group III received $130 \mathrm{mg} / \mathrm{kg}$ sodium nitrates (NaNO3) and group IV received $130 \mathrm{mg} / \mathrm{kg}$ NaNO3 plus $500 \mathrm{mg} / \mathrm{kg}$ vitamin C. All supplementations were taken as oral single dose daily for 60 days. At the end of experiment, blood samples were subjected to hormonal assay (T3, T4 and TSH serum levels). Also, thyroid glands' specimens were prepared for the optical and electron microscopic examination.

Results: I- The biochemical analyses showed a significant decrease in serum T3 and T4 and a significant increase in TSH.

II-Light microscopic examination of nitrates treated group revealed disturbed thyroid architecture in the form of heterogeneous poorly developed follicles. Enlarged deformed follicles with scanty vacuolated colloid, degenerative empty follicles and some fused follicles with exfoliated cells filled their lumen were observed.

III-Electron microscopic examination showed stratification of follicular epithelial cells. Most of the follicular cells appeared with irregular nuclei, dilation of rER, many vacuoles and an apparent number of lysosomes. Also hypertrophy and hyperplasia of parafollicular-C cells were observed. An improvement of thyroid gland's structure, ultrastructure and function was observed in vitamin $\mathrm{C}$ added group.

In conclusion: This study concluded that nitrate is a thyroid gland disruptor via a mutual interdependence between the follicular, parafollicular and intra-thyroidal mast cells. The supplementation of vitamin $\mathrm{C}$ showed beneficial effects upon biochemical and patho-morphological alterations, developed in thyroid gland following exposure to toxic doses of nitrates. So, the recommendations are limitation of sodium nitrates uses, encourage dietary intake of vitamin $\mathrm{C}$ and routine analysis of thyroid function in the most nitrates' contaminated areas.
\end{abstract}

Keywords Sodium nitrates, Thyroid gland, Vitamin C, Rats, Toxicological, Ultrastructure

\section{Introduction}

T $\mathrm{n}$ the recent years, a considerable attention has been paid to the problem of nitrates due to their intensive use as agricultural fertilizers which reach to humans and animals by different routes (Manassaram et al., 2006; Mande et al., 2012). Nitrates are inorganic chemicals commonly found in the 
environment, foods and in the bodies of living humans and animals. Individuals at risk of exposure to nitrates include workers in industries, where fertilizers and explosives are manufactured (Savci, 2012). The widespread use of nitrate salts in agriculture, food and some pharmaceutical industries coupled with high rates of air-borne nitrogen compounds emission from factories and automobiles make the chances of exposure to these chemicals even more inevitable (Manassaram et al., 2006).

Nitrates accumulate in plants when excessive fertilizers are applied to the soil and when there are unfavorable conditions such as drought, deficiency of soil micro- and macro-elements and treatment of crops with herbicides. Nitrates in the soil eventually end up in different quantities in the foodstuffs of plant origin consumed by man, and their excess quantity in foodstuffs adversely affects man, and animals (Hussein et al., 2012). In fact certain foodstuffs such as maize, guinea corn, carrots, potatoes, sunflower, pumpkins and cabbage are known to cumulate large quantity of nitrates even at the normal fertilizer application rate (150 kilogram/hectare) (Awodi et al., 2005; Manassaram et al., 2006). Workers in fertilizer factories and farmers in some parts of the world, who use bare hands to apply fertilizers in crop farming, are at increased risk of exposure through inhalation and skin contact (Awodi et al., 2005). FAO (2009) determined the amount of chemical fertilizer $(\mathrm{N}+\mathrm{P}+\mathrm{K})$ used in Egypt is 373.2 kilogram/hectare.

The major source of nitrates in the human body is through intake of food and water (IPCS, 1999). Vegetables may account for more than $70 \%$ of the nitrates in a typical human diet (ATSDR, 2001) while, drinking water accounts for up to $21 \%$ of total nitrates intake in a typical human diet (ATSDR, 2001; Manassaram et al., 2006). Nitrates are used as food additives to fix the color of meat, to inhibit oxidation and to prevent toxigenesis (Galaly and Mahmoud 2012).

According to a published report, the poisoning of nitrates was claimed to its conversion into nitrites within the alimentary tract (Manassaram et al., 2006). Nitrites may react with amines in the food to form potentially cytotoxic carcinogenic nitrosamines (Muller et al., 1986; Galaly and Mahmoud 2012). Excessive quantities of nitrates and nitrite consumption through food can be harmful to health (Chan, 2011).

The ability of animals to resist the toxic effects of environmental agents is dependent on the detoxication and antioxidant systems. Recently, several nutrients and other chemicals are effective antioxidants, such as vitamins, trace elements, amino acids and their derivatives, fatty acids and plant phenolics (Ayo et al., 2006; Suteu et al., 2007). As vitamins are known to be potent antioxidants and their administration may augment the function of endogenous free radical scavengers, the aim of the present study was to investigate the possible alleviating properties of vitamin $\mathrm{C}$ as an antioxidant to counteract the toxic effect of nitrates on albino rats' thyroid gland structure and function.

\section{Materials and methods}

\section{Experimental animals}

Thirty two adult male albino rats of weights ranging from $150-180 \mathrm{~g}$ were used and obtained from the Unit for Laboratory Animals at Faculty of Veterinary Medicine, Zagazig University. They were housed in standard polypropylene cages with stainless steel wire lids. Animals were maintained at a constant room temperature of $20-23^{\circ} \mathrm{C}$ and free access to feed (standard commercially available pellets for laboratory rodents) throughout the study.

\section{Chemicals and drugs}

Sodium Nitrates 98\% pure (NaNO3) M.W. 84.99 was provided by the British Drug Houses LTD. B.D.H. Laboratory Chemicals Division Pool England.

Vitamin C (L-ascorbic acid) was obtained from Kahira Pharm. and Chem. Ind. Co.

\section{Dosage and route of administration}

Sodium Nitrates (NaNO3): experiments using rats have shown that the LD50 to be $1300 \mathrm{mg} / \mathrm{kg}$ body weight. The dose used was1/10 of the LD50 which is equal to $130 \mathrm{mg} / \mathrm{kg}$ b. wt. Sodium nitrates solution (10\%) was prepared by dissolving in distilled water (DW), and was given orally by gastric tube, single dose/day for 60 days (Zaki et al., 2004).

Vitamin C was given at the dose $500 \mathrm{mg} / \mathrm{kg}$ dissolved in $1.0 \mathrm{ml} \mathrm{DW/} \mathrm{day} \mathrm{(vehicle)} \mathrm{by} \mathrm{the} \mathrm{same}$ route (Hussein et al., 2012).

\section{Experimental schedule}

Rats were left for one week for acclimatization, and then they were randomly divided into four groups as follow:

- Group (I): 8 rats served as control and received $0.1 \mathrm{ml} \mathrm{DW}$.

- Group (II): 8 rats received vitamin C (500mg/kg).

- Group (III): 8 rats received $130 \mathrm{mg} / \mathrm{kg} \mathrm{NaNO} 3$.

- Group (IV): 8 rats received 130 $\mathrm{mg} / \mathrm{kg}$ NaNO3 plus $500 \mathrm{mg} / \mathrm{kg}$ vitamin $\mathrm{C}$.

At the end of experiment, rats were anaesthetized by intra-peritoneal injection of sodium thiopental in a dose of $50 \mathrm{mg} / \mathrm{kg}$.

\section{Biochemical study}

Venous blood samples withdrawn from the retroorbital sinus were collected, left to coagulate, centrifuged at $3000 \mathrm{rpm}$ for $20 \mathrm{~min}$. Clear sera were separated into small glass tubes and stored at $-20^{\circ} \mathrm{C}$ until analysis. A hormonal assay was carried out to determine the serum levels of T3, T4, and TSH using commercially available Chemiluminescence Immunoassay (CLIA, catalogue no. ABIN504750; ABIN, Canoga Park, C.A. USA) following the manufacturer's instructions.

\section{Histological study}

The thyroid glands were dissected out in two stages to avoid tissue damage. Firstly, the neck was opened via a 
longitudinal incision; the larynx was exposed and cut via a horizontal plane superior and inferior to the thyroid gland. Then applied for the following:

\section{a. Light microscopic preparations}

One lobe of thyroid glands was fixed in $10 \%$ neutral buffered formalin for 24 hours. The tissue was routinely processed for paraffin technique, sectioned at $5 \mu \mathrm{m}$ thickness and stained with Haematoxylin and Eosin (Kiernan, 2000).

\section{b. Electron microscopic preparations}

Subsequent cutting of the other lobe of thyroid glands into small pieces about $1 \mathrm{~mm}^{3}$ were fixed in $2.5 \%$ glutaraldehyde, in $0.1 \mathrm{M}$ phosphate buffer(PBS) for 3 hours at $4 \mathrm{C}^{\circ}$, post-fixed in $1 \%$ osmium tetraoxide, washed in PBS, dehydrated in serials of ethyl alcohol, embedded in epoxy resin. For histological assessment, sections of $0.5 \mu \mathrm{m}$ thickness, stained with toluidine blue and photographed. For transmission electron microscopic(TEM) assessment, ultrathin sections $(80 \mathrm{~nm})$ were stained with uranyl acetate and lead citrate (Glauert and Lewis, 1998), examined and photographed using a JEOL 1010 electron microscope at the Mycology and Regional Biotechnology Center, Al Azhar University, Cairo, Egypt.

\section{Statistical study}

Statistical analysis was performed on all parameters. The obtained data were expressed as mean values \pm standard deviation and analyzed using ANOVA test. Results were considered to be statistically significant when $\mathrm{P}$ values are less than 0.05 $(\mathrm{P}<0.05)$.

\section{Results}

\section{Biochemical results}

All the examined parameters in vitamin $\mathrm{C}$ treated group(II) were similar to the control group(I). No significant changes in T3, T4, and TSH were detected (Tables and Histograms 1, 2, 3). Nitrates treated rats showed a significant decrease in T3 and T4 levels with subsequent increase in TSH. Treating animals with nitrates and vitamin $\mathrm{C}$ induced a significant decrease in previous parameters when compared with nitrates treated group (Tables and Histograms 1, 2, 3).

\section{Histological results}

\section{Light microscopic examination}

\section{Control groups (I and II)}

Both groups (I and II) showed nearly similar histological findings. Haematoxylin and Eosin (H\&E) and Toluidine blue( $\mathrm{Tb}$ ) stained sections of the thyroid glands revealed that the gland had a thin connective tissue capsule and fine trabeculae dividing it into lobules. Their parenchyma was consisted of different sized follicles (Figure 1a). These follicles were lined by flattened to cuboidal cells with oval to rounded nuclei. Their lumens were filled with homogenous acidophilic colloid that exhibits peripheral fine vacuoles. An apparent few number of inter-follicular cells and blood capillaries were seen in-between follicles (Figs. 1b and2) and also fibroblasts with dark elongated flat nuclei were depicted between the follicles (Figure 2).

\section{Nitrates treated group (III)}

$\mathrm{H} \& \mathrm{E}$ and $\mathrm{Tb}$ stained sections from the thyroid glands showed disorganized architecture in the form of different sized pleomorphic follicles with congested blood vessels and apparent number of inter-follicular cells. Some follicles appeared large, deformed, distended with scanty vacuolated colloid, others were small empty follicles (Figure 4a). Few follicles filled with exfoliated cells, fused follicles and also microfollicles were observed. Some follicular cells appeared with darkly stained nuclei. The others with pale rounded nuclei and vacuolated cytoplasm were demonstrated arranged in multi-layers especially at one side with some blood capillaries invading them(Figs. 4b, 5a, andb). Interstitial mast cells were also encountered (Figure 5a). An apparent increased number and size of parafollicular C-cells with pale rounded or oval nuclei and pale cytoplasm were seen. These cells were observed either within follicular epithelium or in the interstitium (Figure 5c).

\section{Nitrates with vit-C treated group (IV)}

$\mathrm{H} \& \mathrm{E}$ and $\mathrm{Tb}$ stained sections from the thyroid glands showed few small follicles with scanty colloid among nearly normal large thyroid follicles (Figure 7a). The follicular walls were lined by flattened to cuboidal cells with oval to rounded nuclei. The follicular lumens were filled with homogenous acidophilic colloid that exhibited peripheral large vacuoles. Some inter-follicular cells were clearly observed in-between follicles (Figs. $7 \mathrm{~b}$ and 8).

\section{Electron microscopic examination}

\section{Control groups (I and II)}

Most of the follicular cells appeared flat with oval nuclei. Their cytoplasm revealed few cisternae of rough endoplasmic reticulum, few vacuoles and also polymorphic lysosomal granules. Their apical border exhibited a little number of regular microvilli projecting into the colloid cavity. Blood capillaries were seen close to their thin basal lamina (Figure 3a). The others appeared cuboidal with nearly rounded euchromatic nuclei resting on thin basal lamina. Their cytoplasm revealed numerous parallel cisternae of rough endoplasmic reticulum and also polymorphic dense lysosomal granules. Their apical borders exhibited numerous microvilli projecting into the evenly dark stained colloid (Figure 3b). Para-follicular cells with large nearly rounded euchromatic nuclei and few electron dense secretory granules were observed inbetween the folicular cells (Figure 3c).

Nitrates treated group (III)

Different forms of follicular lining epithelium were observed. Some follicles were lined by one layer of high cuboidal or columnar cells. Their nuclei were irregular and electron dense (Figure 6a). Others were multi-layered follicles (Figure 6b). In most follicular cells, numerous dilated irregular cisternae of rough endoplasmic reticulum, dense pleomorphic lysosomal 
granules, numerous vacuoles and also great number or aggregated microvilli were observed (Figs. 6a, b). Thickened irregular basal laminae were observed in some follicles (Figure 6c). Blood capillaries invading the follicular epithelial lining (Figure 6aandb), apoptotic nuclei (Figure 6b) and thickened irregular basal lamina were observed in some follicles (Figure 6c). Para-follicular C-cells with euchromatic nuclei, numerous, small, low density secretory granules and small mitochondria were seen (Figure 6d).

\section{Nitrates with Vit-C group (IV)}

The thyroid follicular cells with nearly rounded electron dense nuclei resting on a relatively regular thin basal lamina and slightly pushed by a blood capillary were seen. Their cytoplasm revealed relatively parallel, slightly dilated cisternae of rough endoplasmic reticulum, few vacuoles and also lysosomal granules. Their apical border exhibited numerous microvilli projecting into the colloid (Figure 9a). The parafollicular C-cells with rounded euchromatic nuclei resting on a regular thin basal lamina with numerous, small, low density secretory granules and small mitochondria occupied a large portion of its cytoplasm were observed (Figure 9b).

Table (1): Statistical analysis of (mean \pm SD) of the serum total T3 in $\mu \mathrm{g} / \mathrm{dl}$ of different studied groups.

\begin{tabular}{|l|l|l|}
\hline \multicolumn{1}{|c|}{ Parameter } & \multicolumn{2}{c|}{ T3 in $\boldsymbol{\mu g} / \mathbf{d l}$} \\
\hline Groups & Mean \pm SD & P value \\
\hline Control (I) & $38.00 \pm 0.56$ & \\
\hline Vitamin C treated (II) & $37.5 \pm 0.37$ & $\mathrm{P}>0.05$ \\
\hline Nitrates treated (III) & $31.00 \pm 1.71$ & $\mathrm{P}<0.05$ \\
\hline Nitrates with vit C treated (IV) & $36.00 \pm 0.56$ & $\mathrm{P}>0.05$ \\
\hline
\end{tabular}

$P>0.05$ non-significant, $P<0.05$ significant in comparison with the control group.

Table (2): Statistical analysis of (mean \pm SD) of the serum total T4 in $\mu \mathrm{g} / \mathrm{dl}$ of different studied groups.

\begin{tabular}{|l|c|c|}
\hline \multicolumn{1}{|c|}{ Parameter } & \multicolumn{2}{c|}{ Serum T4 in $\boldsymbol{\mu g} / \mathbf{d l}$} \\
\hline Groups & Mean \pm SD & P-value \\
\hline Control (I) & $4.165 \pm 0.58$ & \\
\hline Vitamin C treated (II) & $4.00 \pm 0.37$ & $\mathrm{P}>0.05$ \\
\hline Nitrates treated (III) & $3.33 \pm 0.29$ & $\mathrm{P}<0.05$ \\
\hline Nitrates with vit C treated (IV) & $3.78 \pm 0.51$ & $\mathrm{P}>0.05$ \\
\hline
\end{tabular}

$P>0.05$ non-significant, $P<0.05$ significant in comparison with the control group.

Table (3): Statistical analysis of (mean \pm SD) of serum TSH in $\mu \mathrm{IU} / \mathrm{ml} \pm$ SD of different studied groups.

\begin{tabular}{|l|c|c|}
\hline \multicolumn{1}{|c|}{ Parameter } & \multicolumn{2}{c|}{ Serum TSH in $\boldsymbol{\mu l U} / \mathbf{m l}$} \\
\hline Groups & Mean \pm SD & P value \\
\hline Control (I) & $0.14 \pm 0.003$ & \\
\hline Vitamin C treated (II) & $0.13 \pm 0.02$ & $\mathrm{P}>0.05$ \\
\hline Nitrates treated (III) & $0.21 \pm 0.31$ & $\mathrm{P}<0.05$ \\
\hline Nitrates with vit C treated (IV) & $0.13 \pm 0.11$ & $\mathrm{P}>0.05$ \\
\hline
\end{tabular}

$P>0.05$ non-significant, $P<0.05$ significant in comparison with the control group.

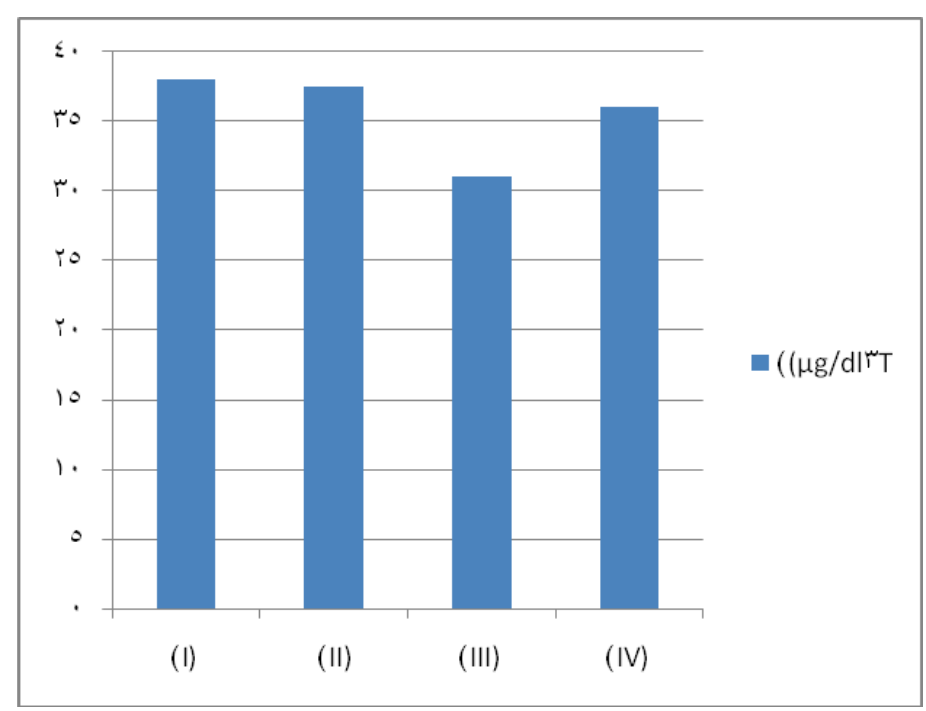

Histogram (1): The mean serum total T3 of different studied groups. 


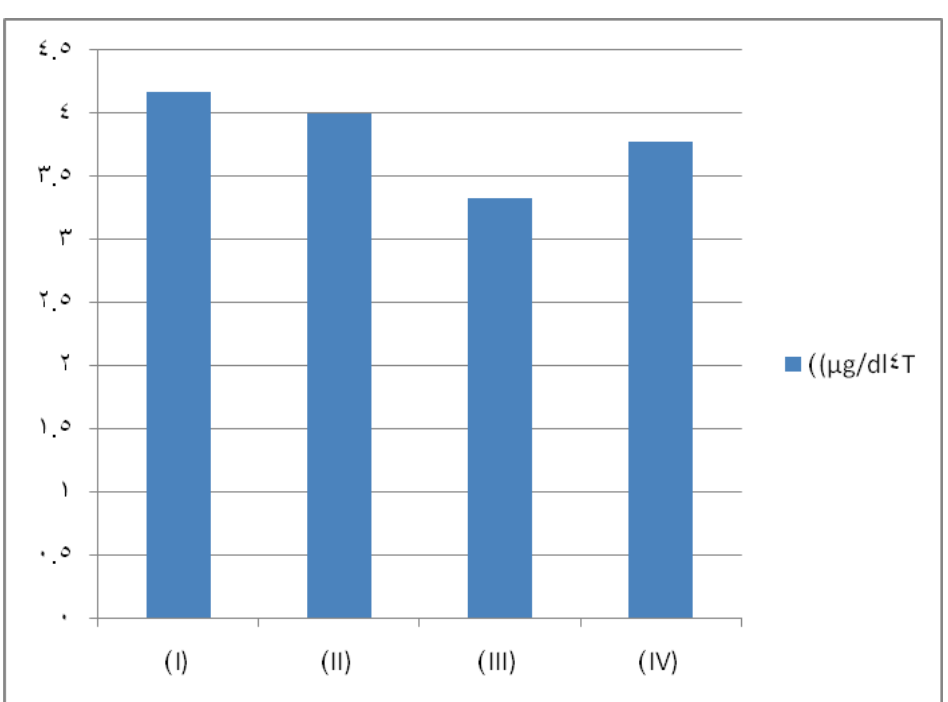

Histogram (2): The mean serum total T4 of different studied groups.

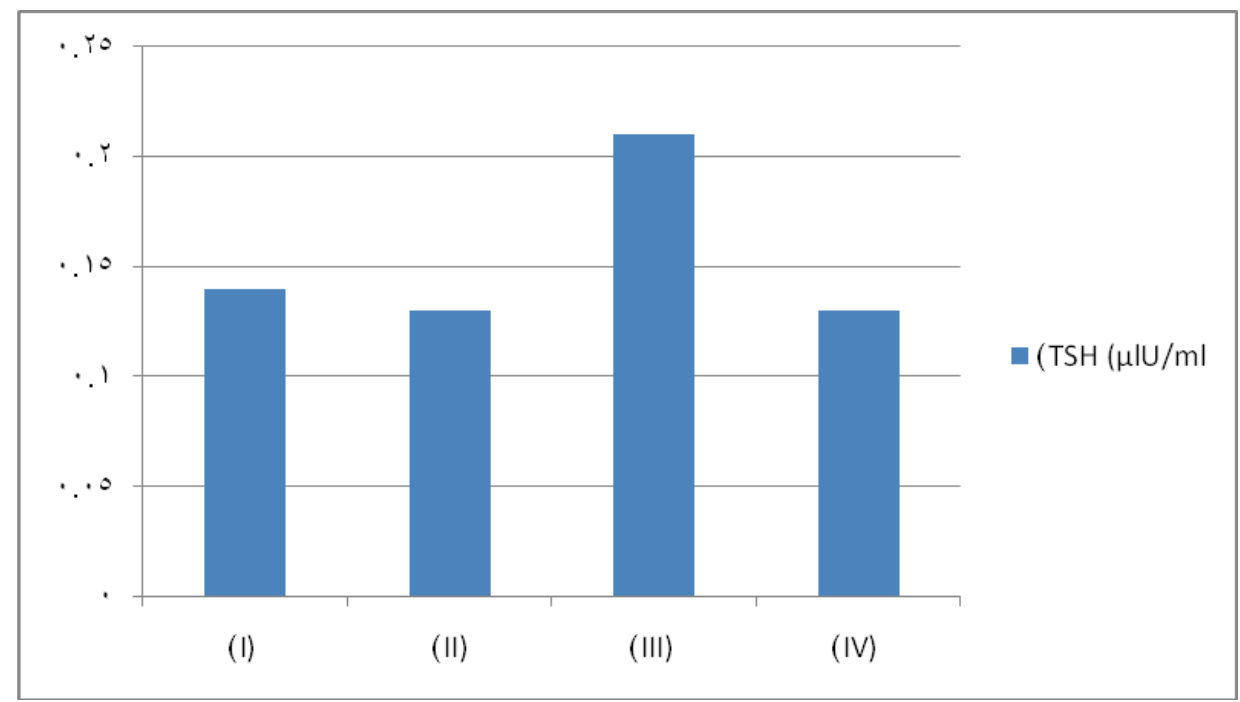

Histogram (3): The mean serum TSH of different studied groups.

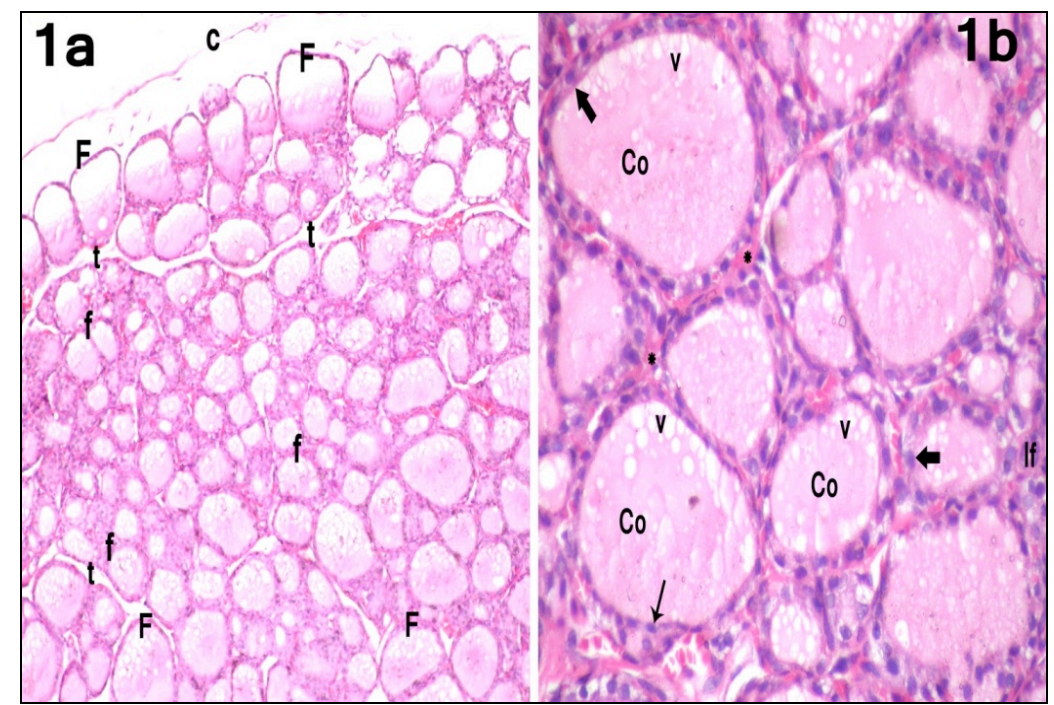

Figure 1a: Showing the normal histological structure of the thyroid gland of control group with thin connective tissue capsule (c) and fine trabeculae (t) dividing the gland into lobules. Its parenchyma showed different sized follicles, large follicles (F) and small follicles (f). (H\&E x100)

1b: A higher magnification of control thyroid section illustrating multiple follicles lined by flattened to cuboidal cells with flattened (arrow) to rounded (thick arrows) nuclei. Their lumens are filled with homogenous acidophilic colloid (co) that exhibits peripheral small vacuoles (v). The inter-follicular cells (If) and blood capillaries (*) are seen in-between follicles. (H\&E x400) 


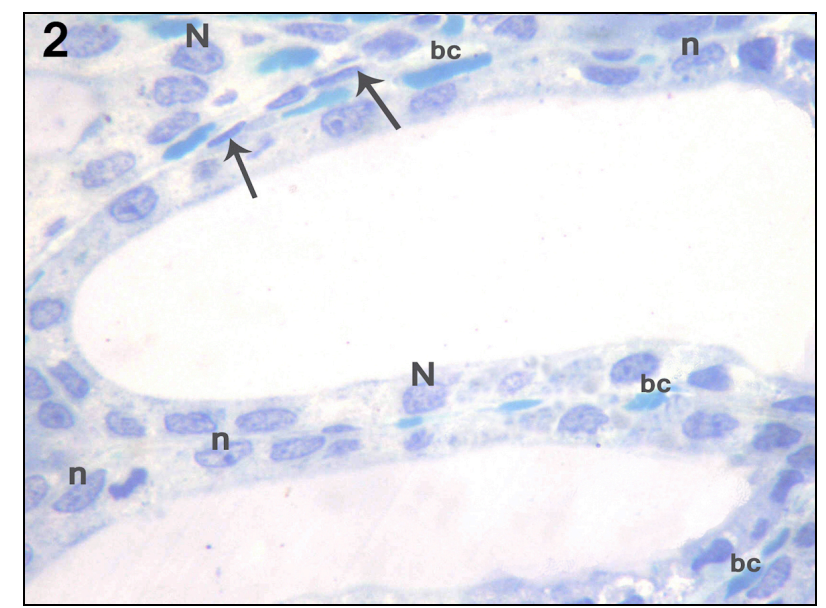

Figure 2: A semi-thin section in the thyroid gland of control group showing two thyroid follicles lined with flattened and low cubiodal cells with oval nuclei (n) rounded (N) nuclei. Fibroblasts with dark elongated flat nuclei (arrows) and blood capillaries (bc) surround the follicles. (Toluidine blue x1000)

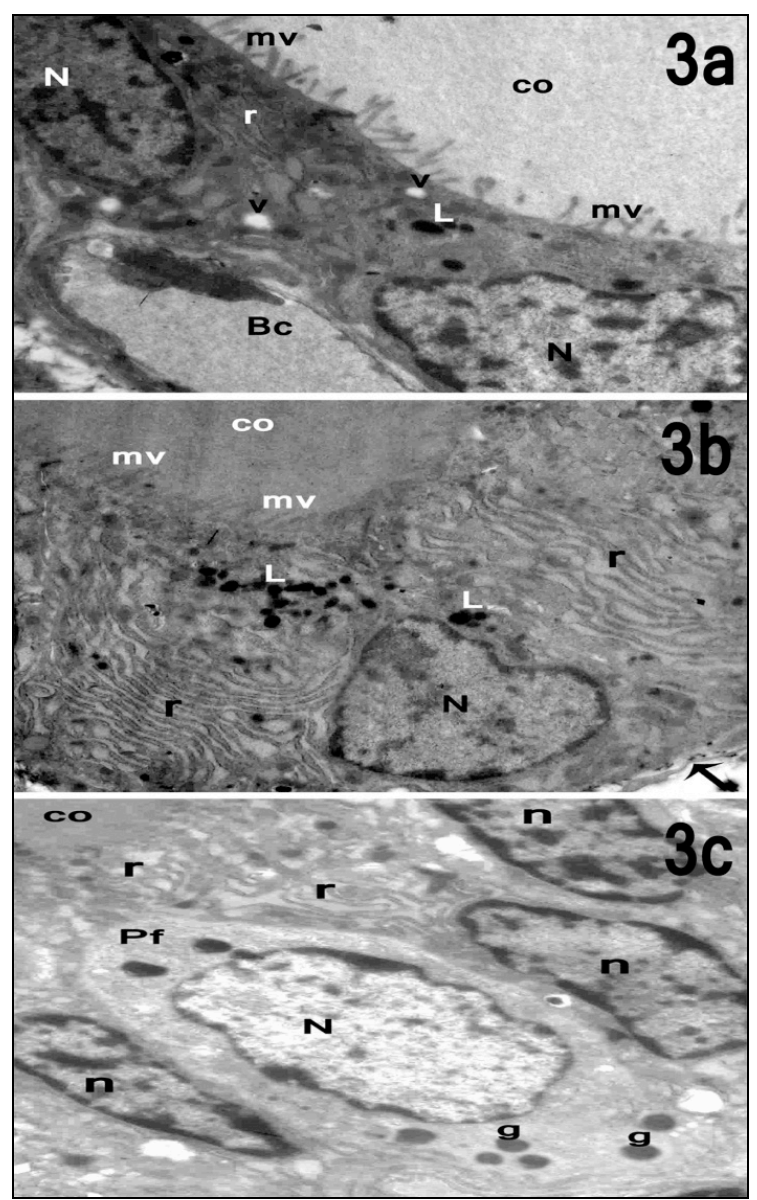

Figure 3a: An ultra-thin section of the thyroid gland of control group showing two flat follicular cells having oval nuclei (N) with clumps of heterochromatin. Their cytoplasm reveals few cisternae of rough endoplasmic reticulum (r), few vacuoles (v) and also polymorphic lysosomal granules (L). Their apical border exhibits little number of regular microvilli (mv) projecting into colloid cavity (co). A blood capillary (Bc) is seen beneath the thin basal lamina. (Mic. Mag. x8000)

3b: Showing a cuboidal follicular cell with rounded euchromatic nucleus $(N)$ resting on thin basal lamina (arrow). Its cytoplasm reveals numerous regular parallel cisternae of rough endoplasmic reticulum (r) and also polymorphic dense lysosomal granules (L). Its apical border exhibits numerous microvilli (mv) projecting into the evenly dark stained colloid (co). (Mic. Mag. x8000)

3c: Showing a parafollicular $C$ - cell (Pf) containing large nearly rounded euchromatic nucleus (N) and few electron dense secretory granules (g). It is surrounded by follicular cells with oval nuclei (n) and cisternae of rough endoplasmic reticulum (r) that separate it from luminal colloid (co). (Mic. Mag. x1500) 


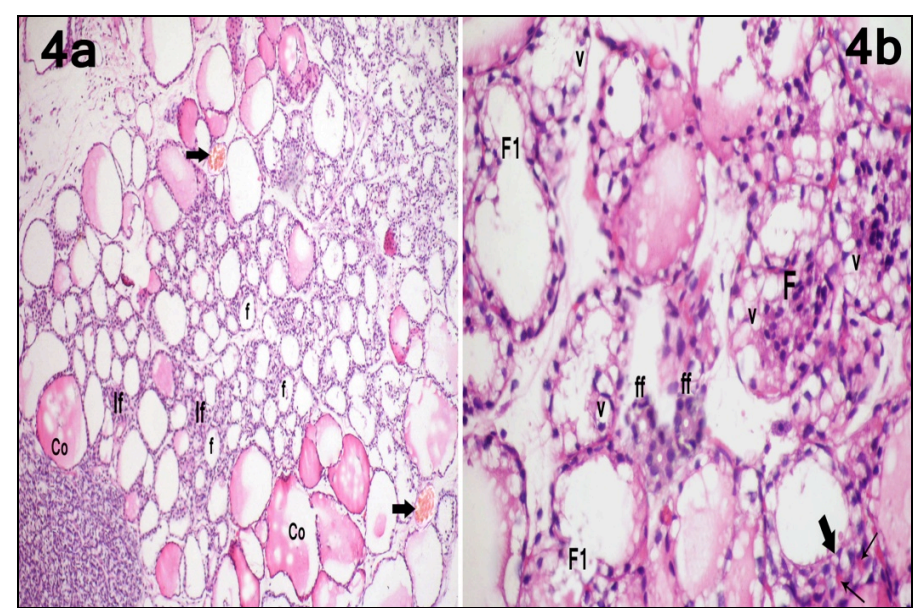

Figure 4a: The thyroid gland of nitrates treated rat (group III) showing pleomorphic different sized and shaped follicles. Some follicles are large, deformed and distended with scanty vacuolated colloid (co) while the others are small empty follicles (f). Congested blood capillaries (arrows) and an apparent number of inter-follicular cells (If) are also observed. (H\&E $\mathbf{x 1 0 0 )}$

4b: A higher magnification of thyroid gland of nitrates treated rat (group III) illustrating disorganized thyroid architecture. Some follicles filled with exfoliated cells (F) and lined by vacuolated follicular cells (v). Others appear fused together (F1). Microfollicles (ff) with constricted or narrow lumens are also seen. Multi-layered follicular cells at one side (thick arrow) of some follicles and blood capillaries (thin arrows) invading them are observed. (H\&E x400)

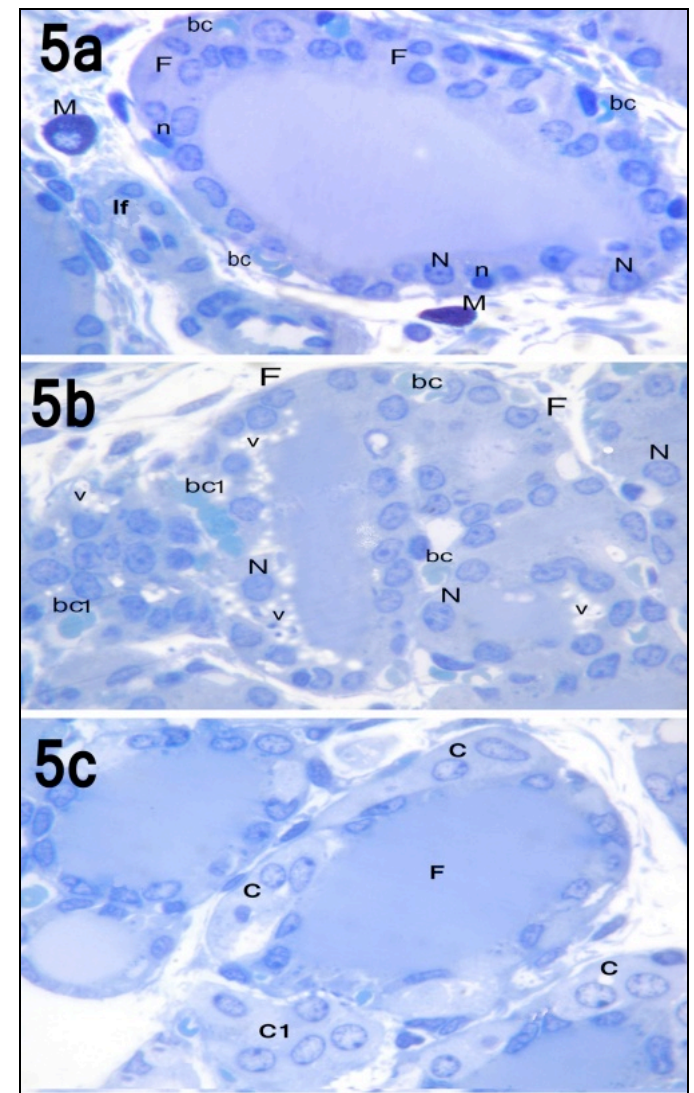

Figure 5a: A semi-thin section in the thyroid gland of nitrates treated rat (group III) showing a follicle (F) lined by multiple layers of follicular cells at one side. Some cells with pale rounded nuclei (N) and the others with darkly stained nuclei (n) are observed. Blood capillaries (bc) invading the follicular epithelium, inter-follicular cells (If) and also interstitial mast cells (M) are illustrated. (Toluidine blue $\mathbf{x 1 0 0 0}$ )

5b: A semi-thin section in the thyroid gland of nitrates treated group (III) showing highly disorganized thyroid architecture. Multiple layers of highly vacuolated follicular cells (v) with pale rounded nuclei (N) at one side of follicle (F) are seen. Numerous blood capillaries (bc) and some of them (bc1) invading the follicular epithelium are noticed. (Toluidine blue $\mathbf{x 1 0 0 0 )}$

5c: A semi-thin section in the thyroid gland of nitrates treated rat (group III) showing apparent increased number and size of parafollicular C-cells (C) with rounded, pale oval nuclei and pale cytoplasm within follicles(F) and in inter-follicular connective tissue (C1). (Toluidine blue x1000) 


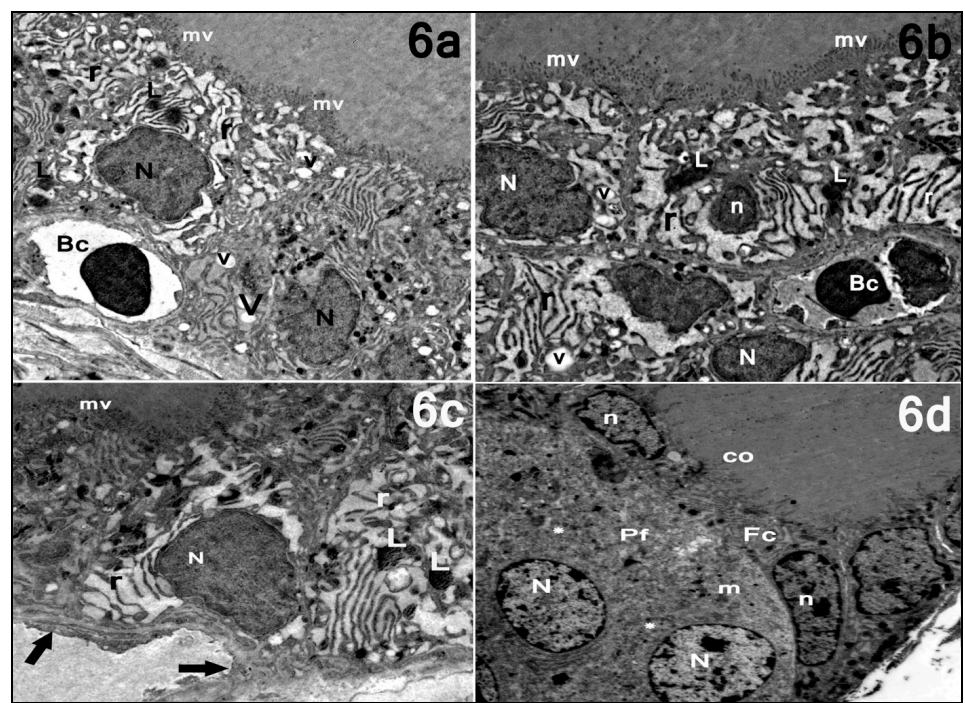

Figure 6a: An ultrathin section of the thyroid gland of nitrates treated rat (group III) showing columnar or high cuboidal follicular cells with electron dark nuclei $(N)$. Numerous dilated irregular cisternae of rough endoplasmic reticulum (r), dense pleomorphic lysosomal granules $(L)$ and also numerous vacuoles (v) are seen. Their apical borders exhibiting a great number or aggregated microvilli (mv). Blood capillary (Bc) is seen indenting the epithelial lining of follicle. (Mic. Mag. x6000)

6b: An ultrathin section of the thyroid gland of nitrates treated rat (group III) showing multi-layered follicular cells invading by a blood capillary $(\mathrm{Bc})$. The nuclei of some follicular cells are irregular heterochromatic ( $N$ ) and others are apoptotic (n). Numerous dilated irregular cisternae of rough endoplasmic reticulum (r), some vacuoles (v) and pleomorphic dense lysosomal granules (L) are seen. Their apical borders exhibit an extensive number or aggregated microvilli (mv). (Mic. Mag. x6000)

6c: An ultrathin section of the thyroid gland of nitrates treated rat (group III) showing a follicular cell with heterochromatic nucleus $(N)$ resting on thickened irregular basal lamina (arrow), irregular dilated cisternae of rough endoplasmic reticulum (r), lysosomal granules (L) and numerous aggregated microvilli (mv). (Mic. Mag. x8000)

6d: An ultrathin section of the thyroid gland of nitrates treated rat (group III) showing a large binucleated parafollicular C-cell (Pf). Both nuclei are euchromatic $(\mathbf{N})$. Numerous, small, low density secretory granules $(*)$ and small mitochondria $(\mathrm{m})$ occupy a large portion of their cytoplasm. They are separated from luminal colloid (co) by flattened follicular cells (Fc) with irregular nuclei (n). (Mic. Mag. x1500)

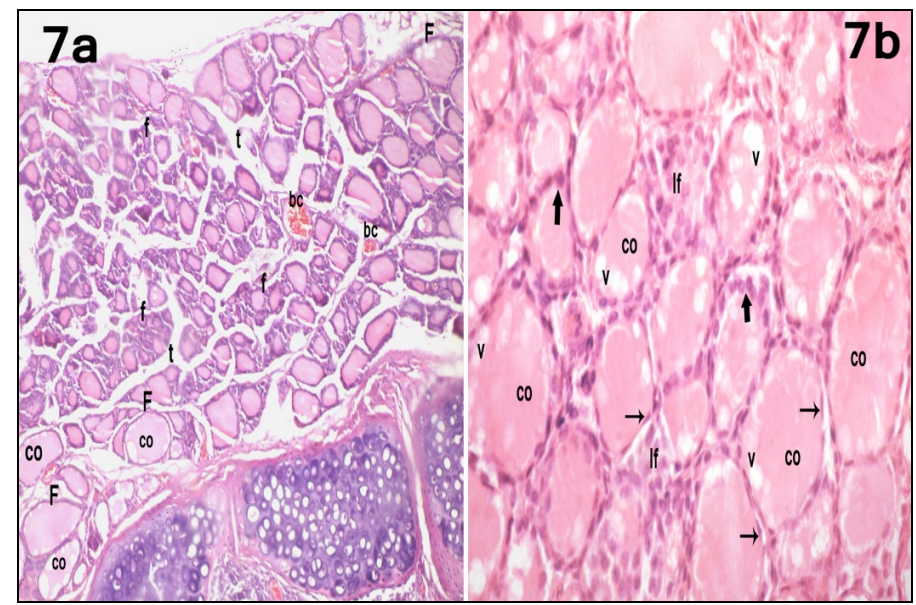

Figure 7a: The thyroid gland of nitrates with vit-C treated rat (group IV) showing most of the thyroid follicles (F) are filled with peripheral vacuolated colloid (co). Small follicles (f) and congested blood capillaries (bc) are still noticed. (H\&E x100)

7b: A higher magnification of thyroid gland of nitrates with vit-C treated rat (group IV) illustrating the follicular walls lined by flattened (arrows) to cuboidal (thick arrows) follicular cells with oval to rounded nuclei. The follicular lumens are filled with homogenous acidophilic colloid (co) that exhibits peripheral large vacuoles (v). Some inter-follicular cells (If) are clearly observed in-between follicles. (Hand E x400) 


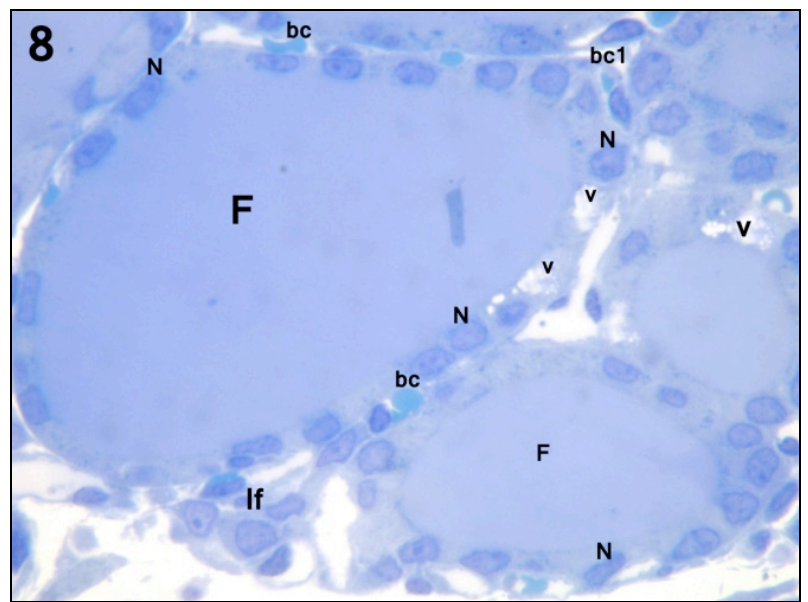

Figure 8: A semi-thin section in the thyroid gland of nitrates with vit-C treated rat (group IV) showing most of thyroid follicles (F) are lined by a single layer of follicular epithelium. Some follicular cells appear with variable shaped nuclei $(\mathrm{N})$ and also few vacuolization (v). Few blood capillaries (bc) and one of them (bc1) invading the epithelial lining of follicle are noticed. A few number of inter-follicular cells (If) are seen. (Toluidine blue x1000)

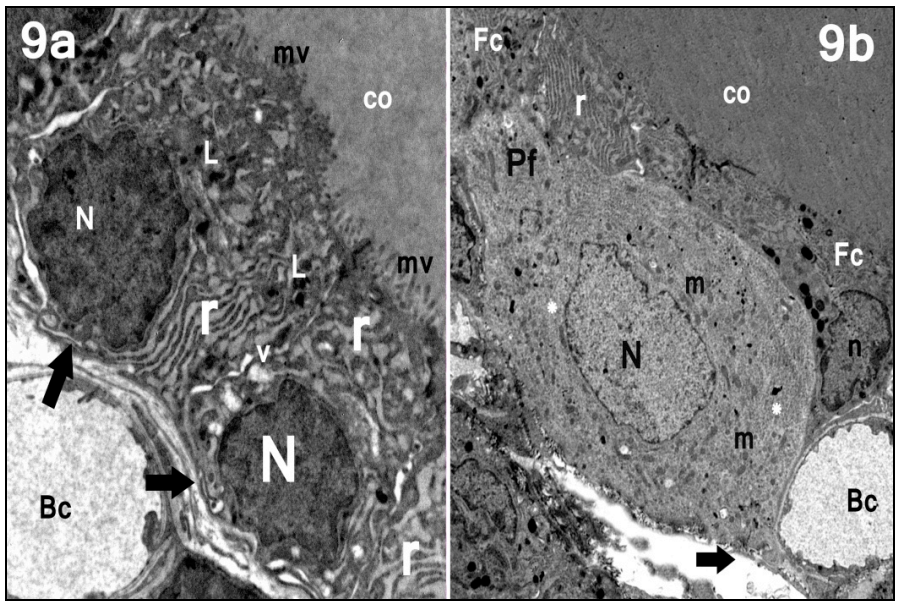

Figure 9a: An ultrathin section of the thyroid gland of nitrates with vit-C treated group (IV) showing follicular cells with irregular nearly rounded nuclei $(N)$ resting on relatively regular thin basal lamina (arrow) slightly pushed by blood capillary $(\mathrm{Bc})$. Their cytoplasm reveals relatively regular dilated cisternae of rough endoplasmic reticulum (r), few vacuoles (v) and also polymorphic lysosomal granules (L). Their apical border exhibits numerous microvilli (mv) projecting into the colloid (co). (Mic. Mag. A x10000)

9b: An ultrathin section of the thyroid gland of nitrates with vit-C treated rat (group IV) showing a large parafollicular C-cell (Pf) with rounded euchromatic nucleus (N) resting on a regular thin basal lamina (arrow). Numerous, small, low density secretory granules (*) and small mitochondria $(\mathrm{m})$ occupied a large portion of its cytoplasm. They are separated from luminal colloid (co) by the follicular cells cytoplasm (Fc) with an irregular nucleus (n) and regular parallel cisternae of rough endoplasmic reticulum (r). Noticed, Blood capillary (Bc) indenting the follicular epithelium. (Mic. Mag. x1500)

\section{Discussion}

The nitrogen cycle had been disturbed by intervention of humans over the last half-century, and as a result, nitrates are steadily accumulating in our water resources (Zaki et al., 2004). Although, nitrates are harmless, their consumption caused various health problems in man. As the harmful effects are contributed to their active metabolite "nitrite" and its consequent reduction into nitric oxide (NO). After absorption of the ingested nitrates, they are rapidly converted into highly reactive and toxic nitrites in presence of high $\mathrm{pH}$ and appropriate intestinal microbial flora. High concentration of nitrates in drinking water and meat products has been implicated in the formation of met-hemoglobinemia and the carcinogenic nitrosamine (El-Wakf et al., 2011; Chan,
2011; Manassaram et al., 2006; Pogoda and Martin, 2001).

The present work was performed to validate the toxic effects of nitrates intake in a short-term experiment (60 days) on the histological structure and function of the male albino rat's thyroid gland and to assess the possible role of vitamin $\mathrm{C}$ supplementation in alleviating these toxic effects. The administration protocol was according to (Zaki et al., 2004 and Hussein et al., 2012).

Available previous study proved that the female' thyroid gland is more sensitive to nitrates than the male one (Eskiocak et al., 2005). In the current work, we chose the male rats to avoid indirect effects of the ovarian tissue damage created by nitrates on 
thyroid gland (Shi et al., 1998; Goldman et al., 2000). The chosen route in this study for exposure was via drinking water to mimic human exposure (Manassaram et al., 2006).

All reactions necessary for the formation of T3 and T4 are influenced and controlled by thyroidstimulating hormone (TSH). So, serum levels of T3, T4 and TSH are considered the reliable indicators of the thyroid function in humans and experimental animals (Kelly, 2000). In the current study, a significant decrease in serum levels of T3 and T4 and a significant elevation of TSH (thyrotropin) was detected in nitrates treated group (Opitz et al., 2006; Yarube, 2011). Several studies indicated that nitrites and $\mathrm{NO}$ ( the metabolites of reduced nitrates ) are well known goitrogenic factors which cause decrease of T3and T4 via blocking of the iodine binding either directly (by inhibition of active transport of iodide into the thyroid via sodium-iodide symporter) or indirectly (by inhibition of $\mathrm{Na} / \mathrm{K}$ ATPase complex) (Chung, 2002; Dohan and Carrasco, 2003). Recently, decreased accumulation of iodide in thyroid gland by nitrates might occur due to decreased activity of thyroid peroxidase that catalyzes the biosynthesis of thyroid hormones at different level (El-wakf et al., 2009). Elevated level of TSH in this study was interpreted as a feedback mechanism to compensate decreased production of thyroid hormones (Mukhopadhyay et al., 2005).

The most striking histological changes recorded in the present work were increased height of follicular epithelium, stratification, outpocking of small follicles from large ones and formation of microfollicles. These results are supported by the findings of many investigators who focused on the influence of nitrates on the thyroid status. They reported thyroid enlargement with decreased thyroid hormones in people drinking polluted water with nitrates either below the WHO standard of nitrates concentration (50 mg/L) (Eskiocak et al., 2005; Kostogrys et al., 2010) or above (Tajtakova et al., 2006). Rajkovic et al., (2006) referred these changes to increased level of TSH as it leads to hypertrophy and hyperplasia of the follicular cells. They noted that excessive concentrations of thyrotropin after long-term application of antithyroid drugs to mice provoke hyperplasia of both the follicular cells and the intrathyroidal mast cells and transiently, the parafollicular C cells. Another hypothesis assumed stimulated follicular cells to the parafollicular and mast cells by their paracrine secretions (Kalisnik et al., 1988).

Extensive vacuolization of colloid in some follicles was depicted by Wang et al. (2009) as increased endocytotic activity of the thyroid gland to release the stored hormones to compensate T3 and T4 deficiency. They hypothesized that these vacuolization is due to increased TSH. The heavily microvillous borders and increased number of lysosomes detected in the current work were in accordance with other researchers by other toxins. This proliferation of microvillus border was explained by Zbucki et al. (2007) and Teng et al.(2009) to facilitate rapid transport and iodination of thyroglobulin across cell membrane.

In the present work, the congested dilated blood capillaries invading or infiltrating the follicles in the nitrates treated group could be attributed to high level of TSH. This finding was coinciding with other studies that reported better vascularization of the gland after methimazole treatment (Cakic-Milosevic et al., 2004; Krohn et al., 2005). Also, nitric oxide (another end product of ingested nitrates) is a relaxant factor, causing vasodilatation, especially in tissue injury or inflammation (Clancy et al., 1992). Mast cells which were frequently seen in the interstitium were documented by Bianco et al. (1983). They observed blocked TSH actions on thyroid gland after treatment with disodium cromoglycate (mast cells stabilizer). So, the intra-thyroidal mast cells are considered as an intermediary factor of TSH actions on thyroid gland. Furthermore, both T4 and T3 serum concentrations were increased after compound BW48-80 (mast cells disrupter polymer). Finally, the active participation of mast cells on TRH and/or TSH secretion was confirmed (Hiromatsu and Toda, 2003). They assumed folliculogenesis and angiogenesis to the growth factors elaborated from intra-thyroidal mast cells. In addition, the mast cell products as tryptase degrade connective tissue interstitium to provide spaces for neovascular sprouts.

Regarding alteration of the nuclear pattern in the current work, all nuclear changes as karyolysis, pyknosis and karyorhexis were considered a consequence of glandular over stimulation by TSH (Kumar et al., 2010). In addition, nitrates induced apoptosis by oxidative stress induced lipid peroxidation and releasing cytochrome $\mathrm{C}$ into the cytosol and further triggering caspase cascades leading to apoptosis (Opitz et al., 2006). The dilatations of endoplasmic reticulum with disturbed lamellar arrangement observed in the present study were explained by Ghadially (1997) in different possibilities. The first theory is due to synthesis of secretory products much more than their removal by transport mechanisms. The second is due to mechanical or enzymatic abnormalities in endoplasmic reticulum which prevent the removal of the normal quantities of synthesized materials (a defect in this transport system). Synthesis of an abnormal secretory product which cannot be removed is another explanation or theory.

Evidence of hyperactivity, hyperplasia and hypertrophy noted in C-cells and follicular cells in nitrates treated group were coinciding with other researchers (Dadan et al., 2003; Martin-Lacava et al., 2009) who referred the presence of enlarged C-cells distributed either in small groups or even singly as a sign of hyperactive thyroid. These observations might point to the possibility of a relationship between the functional state of the thyroid gland and activity of Ccells. Also they suggested that the possible mechanisms involved in the $\mathrm{C}$-cells changes with the thyroid status were line with changes of follicular cells and increased TSH level in hypothyroid rats. In this study, many C-cells were observed in the interstitium. Banovac and De Forteza (1992) referred this to 
elaboration of mast cells' proteolytic enzyme (chymase) which digests fibronectin and vitronectin and leads to destruction of thyroid cellular attachment. Information available showed that nitrates and nitrites induce free radical generation in vivo through the release of nitrite and NO which overwhelm the host antioxidant defense system (Hassan et al., 2009). In addition, chronic toxicity of nitrates has been shown to be connected to the formation of carcinogenic $\mathrm{N}$ nitroso compounds, impairment of acid-base balance, resulting in metabolic acidosis, stores depletion of vitamins C and E stores (Oladele et al., 1997; Hassan et al., 2009) as well as vitamin A level in the body (Dusheyko, 1989; Hassan et al., 2009). Moreover, nitrates, especially in high concentrations, may impair the activity of digestive enzymes and vitamin A metabolism (Dusheyko, 1989). So, in the present study, administration of vitamin C [L-ascorbic acid (AA)] together with sodium nitrates was advantageous as it is an effective antioxidant in many biological systems via its reducing properties and function as an electron carrier (Ambali et al., 2007). AA takes part in redox and hydroxylation pathways, acting as a cofactor for cytochrome P450- dependent hydroxylases in some reactions. AA can also form an ascorbate radical, giving another route to antioxidant activity by destroying free radicals derived from oxygen, including $\mathrm{OH}-, \mathrm{O} 2$ - and superoxide (Whitehead and Keller, 2003). In this role, it may show a synergistic action with other protective enzymes including superoxide dismutase, glutathione peroxidase and catalase (Hassan et al., 2009).

In conclusion, it is concluded that nitrate is a thyroid gland disruptor via a mutual interdependence between the follicular, parafollicular and intrathyroidal mast cells. The supplementation of vitamin $\mathrm{C}$ showed beneficial effects upon biochemical and pathomorphological alterations, developed in thyroid gland following exposure to toxic doses of nitrates. So, the recommendations are limitation of sodium nitrates uses, encourage dietary intake of vitamin $\mathrm{C}$ and routine analysis of thyroid function in the most nitrates' contaminated areas.

\section{References}

Ambali S, Akanbi D, Igbokwe N et al., (2007): Evaluation of subchronic chlorpyrifos poisoning on haematological and serum biochemical changes in mice and protective effect of vitamin C. The Journal of Toxicological Sciences. 32 (2): 111-120.

ATSDR (2001): Agency for Toxic Substances and Disease Registry. Nitrates/nitrite toxicity. In: Case Studies in Environmental Medicine. Department of Health and Human Services, Wigington, P. S. (Ed), DTEM, U.S.A., 22.

Awodi S, Ayo JO, Nwude CI et al., (2005): Effects of sodium nitrite and ascorbic acid on the erythrocyte osmotic fragility in Red Sokoto Goats. Proceedings of 10th Annual Conference of the Animal Science
Association of Nigeria (ASAN) University of Ado-Ekiti, Nigeria, $65-68$.

Ayo JO, Minka NS and Mamman M (2006): Excitability scores of goats administered ascorbic acid and transported during hot-dry conditions. Journal of Veterinary Science. 7(2):127-131.

Banovac K and De Forteza R (1992): The Effect of Mast Cell Chymase on Extracellular Matrix: Studies in Autoimmune Thyroiditis and in Cultured Thyroid Cells. Int Arch Allergy Immunol. 99:141-149.

Bianco AC, Nunes MT and Douglas CR (1983): Influence of mast cells on thyroid function. Endocrinol Exp. 17(2):99-106.

Cakic-Milosevic M, Korac A and Davidovic V (2004): Methimazole Induced Hypothyroidism in Rats: Effects on Body Weight and Histological Characteristics of Thyroid Gland. Jugoslov. Med. Biohem. 23(2): 143-147.

Chan TYK (2011): Vegetable-borne nitrates and nitrite and the risk of methaemoglobinaemia. Toxicology Letters 200(1-2): 107-108.

Chung, J. K. (2002): Sodium iodine symporter: Its role in nuclear medicine. J. Nucl. Med., 43: 11881200.

Clancy RM, Piziak JL and Abramson SB (1992): Nitric Oxide, an Endothelial Cell Relaxation Factor, Inhibits Neutrophil Superoxide Anion Production via a Direct Action on the NADPH Oxidase J. Clin. Invest. 90: 1116-1121.

Dadan J, Zbucki RL, Sawicki B, et al., (2003): Activity of the Thyroid Parafollicular C-Cells in Simple and Hyperactive Nodular Goiter Treated Surgically Preliminary Investigations. Folia. Morphol. 62: 443-445.

Dohan O and Carrasco N (2003): Advances in Na+/Isymporter (NIS) research in the thyroid and beyond. Mol. Cell Endocrin. 213: 59-70.

Dusheyko AA (1989): Vitamin A - Metabolism and Function. Naukova Dumka, Kiev. pp 288.

El-wakf AM, Hassan HA, El-said A et al., (2009): Hypothyroidism in Male Rats of Different Ages Exposed to Nitrates Polluted Drinking Water. Research Journal of Medicine and Medical Sciences. 4(2): 160-164.

El-wakf AM, Elhabiby EM, El-kholy WM et al., (2011): Use of Tumeric and Curcumin to Alleviate Adverse Reproductive Outcomes of Water Nitrates Pollution in Male Rats. Nature and Science. 7(7): 229-239.

Eskiocak S, Dundar C, Basoglu T et al., (2005): The effects of taking chronic nitrates by drinking water on thyroid functions and morphology. Clin. Exp. Med. 5: 66-71.

FAO (2009): Resource STAT-Fertilizer. Food and Agriculture Organization of the United Nations.

Galaly SR and Mahmoud MS (2012):The protective effect of vitamin A against sodium nitrate induced toxicity in liver and kidney of albino rats: histological and ultrastructural study. Journal of American Science. 8(12) 293-308. 
Ghadially FN (1997): Endoplasmic Reticulum in: Ghadially FN (ed) Ultrastructural Pathology of the Cell and Matrix Butter-WorthHeinemann, Boston. pp 433-602.

Glauert AM and Lewis PR (1998): Biological Specimen Preparation for Transmission Electron Microscopy. Volume 17, Portland Press, London.

Goldman JM, Laws SC, Balchlk SK et al., (2000): Endocrine- Disrupting Chemicals: Prepubertal Exposures and Effects on Sexual Maturation and Thyroid Activity in the Female Rat. A Focus on the EDSTAC Recommendations. 30(2): 135-196.

Hassan HA, El-Agmy SM, Gaur RL, et al., (2009): In vivo evidence of hepato- and reno-protective effect of garlic oil against sodium nitrite induced oxidative stress. Int $\mathrm{J}$ Biol Sci. 5(3):249-255.

Hiromatsu Y and Toda S (2003): Mast Cells and Angiogenesis. Microsc. Res. Tech. 60: 6469.

Hussein HK, Elnaggar MH, Al-Dailamy JM (2012): Protective role of Vitamin $\mathrm{C}$ against hepatorenal toxicity of fenvalerate in male rats. Global Advanced Research Journal of Environmental Science and Toxicology. 1(4): 060-065.

IPCS (1999): International Programme on Chemical SafetyNitrates and nitrites. Poisons, Information Monograph (Group Monograph) GO 16, Chemical. Ruse M. (Ed.), 35.

Kalisnik M, Vraspir-Porenta O, Kham-Lindtner T, et al., (1988): The interdependence of the follicular, parafollicular, and mast cells in the mammalian thyroid gland: a review and a synthesis. Am J Anat. 183: 148-157.

Kelly GS (2000): Peripheral Metabolism of Thyroid Hormones: A Review. Altern. Med. Rev.; 5: 306-333.

Kiernan J (2000): Histological and Histochemical Method Theory and Practice. 3rd ed. Pp: 129139. Oxford.

Kostogrys R, Pisulewskil P, Pecio A et al., (2010): Goitrogenic Effects of Allylisothiocyanate, Nitrates and Nitrite in Rats and Alleviating Properties of Iodine and Selenium Supplements. Pol. J. Food Nutr. Sci. 60(2): 165-173.

Krohn K, Führer D, Bayer Y et al., (2005): Molecular pathogenesis of euthyroid and toxic multinodular goiter. Endocr. Rev. 26, (4): 504-524

Kumar V, Abbas AK, Fausto N et al., (2010): Endocrine System. In: Robbins and Cortan Pathologic Basis of Disease, $8^{\text {th }}$ ed., Saunders, Elsevier Inc. 1096-1164.

Manassaram DM, Backer LC and Moll DM (2006): A review of nitrates in drinking water: Maternal exposure and adverse reproductive and developmental outcomes. Environmental Health Perspective. 114 (3): 320 - 327.
Mande SA, Liu M, Djaneye-Boundjou G, et al., (2012): Nitrates in drinking water: A major polluting component of groundwater in gulf region aquifers, south of Togo. International Journal of the Physical Sciences. 7(1):144 152.

Martin-Lacava I, Borrero MJ, Utrilla JC, et al.,(2009): C-Cells Evolve at the Same Rhythm as Follicular Cells When Thyroidal Status Changes in Rats. J. Anat. 214:301-309.

Mukhopadhyay S, Ghosh D, Chatterjee A et al., (2005): Evaluation of possible goitrogenic and anti-thyroidal effect of nitrates, a potential environmental pollutant. Indian J. Physiol. Pharmacol. 49(3): 284-288.

Muller RL, Hgel H, Ruppin HJ and Domschki V (1986): Nitrates and nitrite in normal gastric juice. Oncology. 43: 50-53.

Oladele SB, Ayo JO and Adaudi AO (1997): The emergence of nitrates and nitrite poisoning in humans and domestic animals. West African Journal of Pharmacology and Drug Research. 13: 50 - 58.

Opitz R, Trubiroha A, Lorenz C et al.,(2006): Expression of sodium-iodide symporter mRNA in the thyroid gland of Xenopus laevis tadpoles: developmental expression, effects of antithyroidal compounds, and regulation by TSH. Journal of Endocrinology. 190: 157170.

Pogoda JM and Martin PS (2001): "Maternal cured meat consumption during pregnancy and risk of paediatric brain tumour in offspring: potentially harmful levels of intake." Public Health Nutr. 4(2):183-189.

Rajkovic V, Matavulj M and Johansson O(2006): Light and electron microscopic study of the thyroid gland in rats exposed to powerfrequency electromagnetic fields. The Journal of Experimental Biology. 209: 3322-3328.

Ramsden JD (2000): Angiogenesis in the Thyroid Gland. J. Endocrinol. 166: 475-480.

Savci S (2012): An Agricultural Pollutant: Chemical Fertilizer. International Journal of Environmental Science and Development. 3(1): 77- 80.

Shi Q, Hales DB and Emanuele NV et al., (1998):"Interaction of ethanol and nitric oxide in the hypothalamic- pituitary-gonadal axis in the male rat," Alcoholism: Clinical and Experimental, vol. 22, no. 8, pp 1754-1762.

Suteu R, Altuntas I, Buyukvanli B et al., (2007): The effects of diazozin on lipid peroxidation and antioxidant enzymes in rats erythrocytes: role of vitamins $\mathrm{E}$ and $\mathrm{C}$. Toxicology and Industrial Health. 23(1): 13 - 17.

Tajtakova M, Semanova Z, Tomkova Z, et al., (2006): Increased thyroid volume and frequency of thyroid disorders signs in school children from nitrates polluted area. Chemosphere. (62): 559 - 564.

Teng X, Shan Z, Teng W et al., (2009): Experimental Study on the Effects of Chronic Iodine Excess 
on Thyroid Function, Structure, and Autoimmunity in Autoimmune-Prone NOD.H-2h4 Mice. Clin. Exp. Med. 9(1): 5159.

Wang H, Yang Z, Zhou B, et al., (2009): Fluoride Induced Thyroid Dysfunction in Rats: Roles of Dietary Protein and Calcium Level. Toxicol. Ind. Health. 25(1): 49-57.

Whitehead CC and Keller T (2003): An update on ascorbic acid in poultry. World's Poultry Science Journal 59:161-184.

Yarube IU (2011): Nitrates induced oxidative stress and the effects of dietary antioxidant vitamins
C, E, and A: ingestion from experimental and clinical studies. Bayero Journal of Pure and Applied Sciences. 4(2): 69 - 79.

Zaki A, Chaoui AA, Talibi A et al., (2004): Impact of nitrates intake in drinking water on the thyroid gland activity in male rat. Toxicol. Lett 147: 27-33.

Zbucki RL, Winnicka MM, Sawicki B, et al., (2007): Alteration of Parafollicular (C) Cells Activity in the Experimental Model of Hypothyroidism in Rats. Folia Histochemica Et. Cytobiologica. 45(2): 115-121.

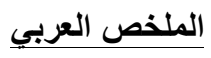

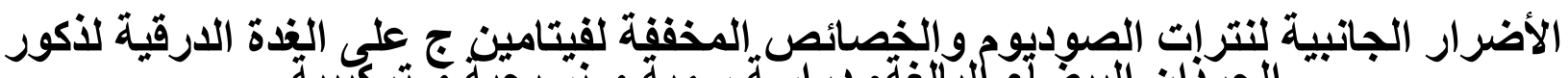

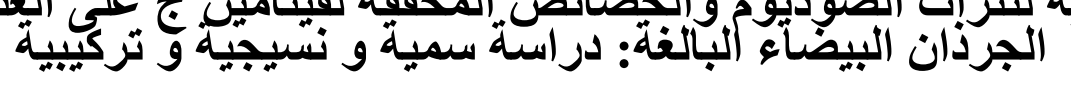

\section{زينب عبد الله جودها محمود اسماعيل و إيمان محمود عسكر 1و زكريا الظواهرى2}

المقدمة: في السنوات الأخيرة، يوجد اهتمام كبير لمشكلة النترات نظر الاستخدامها المكثف كأسمدة زر اعية التي

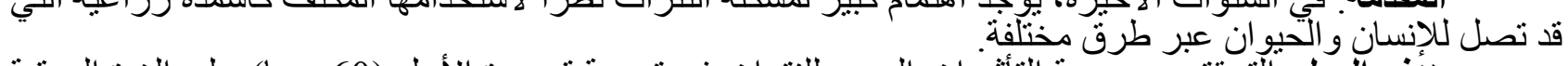

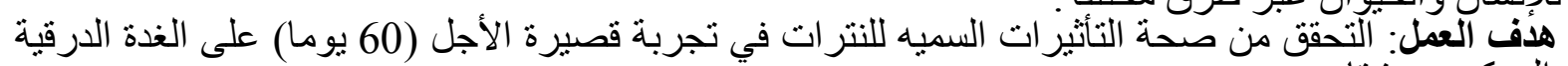

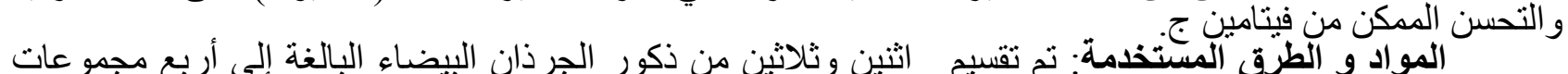

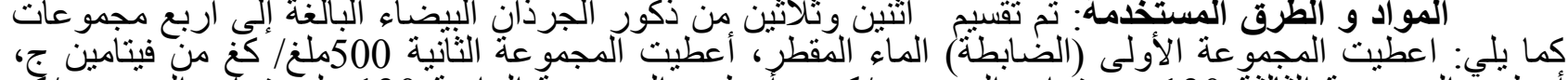

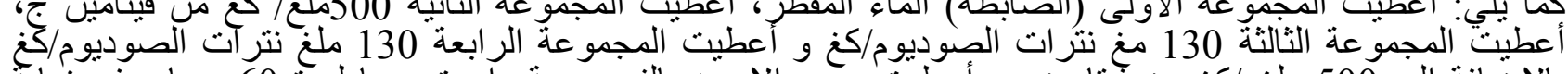

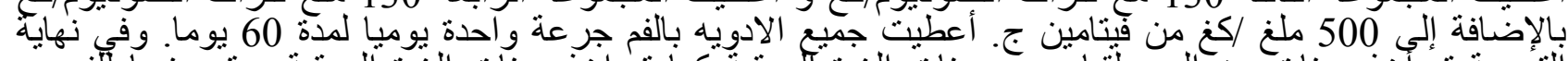

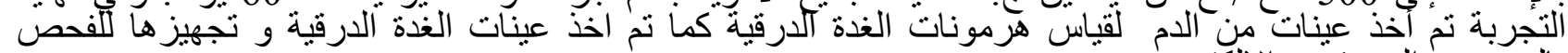
بالمجهرين الضوبئى و الالكترونى.

1. التحاليل البيوكيميائية : أظهر الفحص الهرموني انخفاض ملحوظ في T3 و T4 في الدم وزيادة كبيرة النتائج

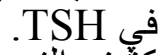

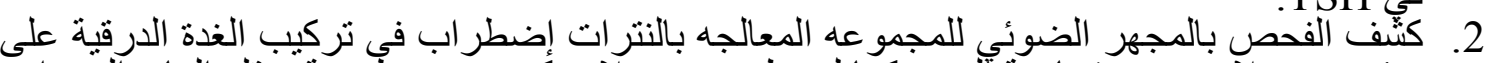

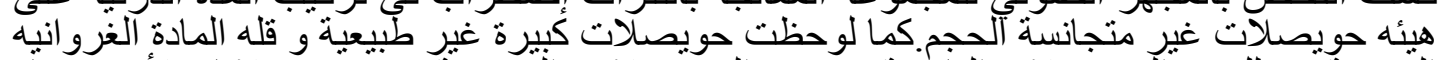

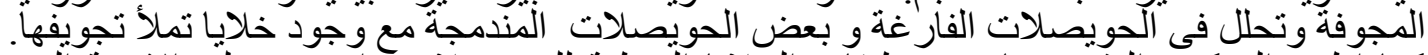

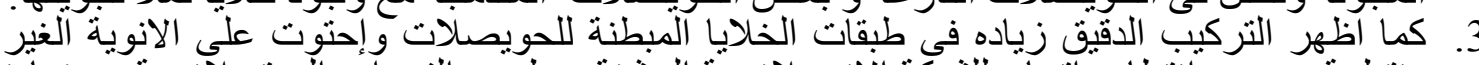

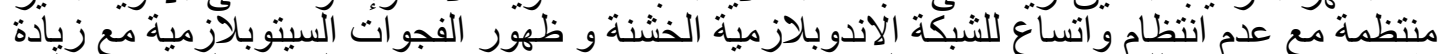

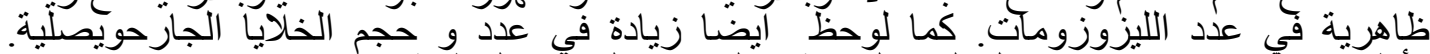

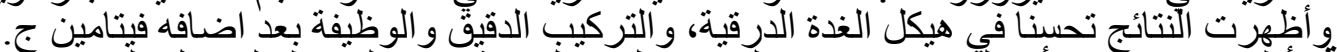

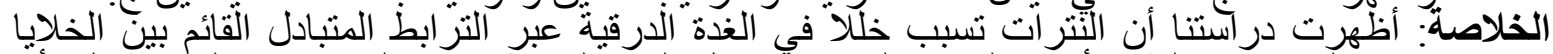

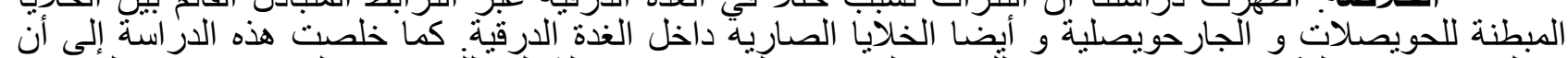

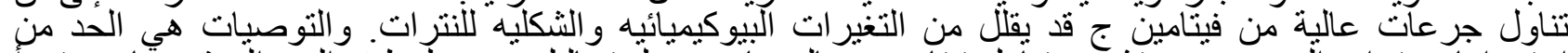

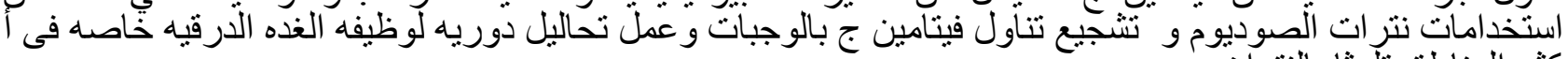

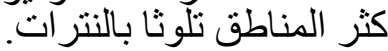

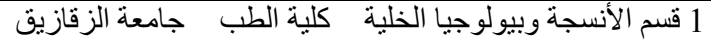

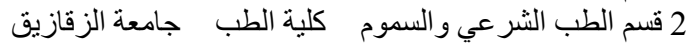

